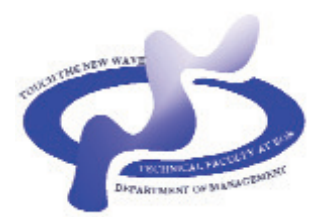

www.sjm06.com
Serbian

Journal of

Management

\title{
THE IMPACT OF MACROECONOMIC DETERMINANTS AND TAX FORM ON INFLATION IN SELECTED BALKAN COUNTRIES
}

\author{
Nada Milenković, Branimir Kalaš*, Vera Mirović and Jelena Andrašić \\ University of Novi Sad, Faculty of Economics in Subotica, \\ Segedinski put 9-11, Subotica, Serbia
}

(Received 26 February 2018; accepted 07 June 2019)

\begin{abstract}
The goal of this research is to reflect how the gross domestic product, unemployment, real interest rate, savings, government expenditures and value-added tax effect on inflation in selected Balkan countries for period 2008-2016. Research examines the impact of macroeconomic determinants on price movements in the general level, measured by the annual rate of inflation. Selected countries are Albania, Bosnia and Herzegovina, Croatia, Montenegro, North Macedonia, Serbia and Slovenia. This paper includes model where inflation is the dependent variable, while gross domestic product, unemployment, real interest rate, saving, government expenditures and value-added tax represent independent variables. Authors used LLC test and VIF test for stationary and multicollinearity, where confirmed that model is adequately designed. Using Hausman test, fixed effect model is chosen, where results have shown that gross domestic product, unemployment and value-added tax have a statistically significant impact on inflation compared to other explanatory variables in the model.
\end{abstract}

Keywords: inflation, macroeconomic determinants, panel model, Balkan countries.

\section{INTRODUCTION}

Inflation can be simply defined as a price rise in the general level in one country. Friedman (1976) points out that inflation is always and everywhere a monetary phenomenon and low inflation has an important place in the economic policy of each country because in the case of the pronounced volatility of this indicator may lead to adverse implications for economic growth (Klomp \& Haan, 2009). Haderi et al. (1999) point out that when a country moves from a planned economy to a market economy, inflation could be a direct problem for the government. In the past, countries of the former Yugoslavia had negative experiences with inflation and Žižmond

\footnotetext{
*Corresponding author:branimir.kalas@ef.uns.ac.rs
}

DOI:10.5937/sjm15-16685 
(1991) indicates the annual inflation rate reached $1255.7 \%$ in 1989 . The same author argues it was the result of inadequate measures of economic policy and economic system, as well as inflationary expectations.

\section{LITERATURE REVIEW}

There are many determinants which affect on inflation where gross domestic product and unemployment are the most common variables that related with inflation. There are a large number of papers which examine the nexus between these variables (Dotsey \& Sarte, 2000; Malik \& Chodwhury, 2001; Fountas 2010; Ferdous \& Shahid, 2013; Enu et al., 2013; Amin \& Manu, 2014; Yelwa, 2015; Ademola \& Badira, 2016; Baharumshah et al., 2016). Malik and Chowdhury (2001) found a positive and statistically significant relationship between inflation and gross domestic product, noting that growth sensitivity on changes of inflation rate is less than inflation sensitivity on changes of economic growth. Ademola and Badira (2016) researched nexus between gross domestic product, inflation and unemployment and noticed there is a positive relationship between these variables. Contrary, Jha and Dang (2012) investigates that when inflation rate exceeds $10 \%$, it has a negative effect on economic growth. Enu et al. (2013) found a negative correlation between inflation and gross domestic product and determined when inflation increases for $1 \%$, it leads to the decline of economic growth for $0.08 \%$. Also, Yelwa et al. (2015) determined a negative relationship between these variables with no statistically significance. Likewise, Rother (2002) cited Domac-Elbirt model (1998) which analysed causality between macroeconomic determinants and inflation and they identified that money and nominal exchange rate drives inflation. Bağci and Ergüven (2015) explored medium positive correlation between inflation rate and interest rate in Turkey for the period 2002-2015.

On the other hand, Attari and Javed (2013) investigated the relationship between inflation rate, economic growth and government expenditures in Pakistan. Using time series data during the period 19802010, the results confirmed there is a long term relationship between these variables, while in the short term, the inflation does not affect the economic growth. The study showed that there is unidirectional causality between inflation rate and economic growth, as well as economic growth and government expenditures. Milenković et al. (2017) found that there is no statistically significant correlation between inflation and gross domestic product, while monetary aggregate M3 is significantly correlated to inflation. Using annual time series data from 19802013, Edeme and Ifelunini (2015) examined the relationship between inflation, economic growth and savings in Nigeria. The study manifested that inflation and real interest rate are negatively related with economic growth, as well as economic growth, unemployment and real interest rate negatively affected inflation rate. Mehrara and Sujoudi (2015) found no significant effect of government on inflation in Iranian economy for the period 1959-2010.

In addition to macroeconomic factors, taxes are often associated with inflation. Value-added tax is tax form that often associated with inflation and his relevance is manifested through fact that movement can cause changes in inflation. There are many studies which are focus on relationship between inflation and tax forms (Schall, 
1984; Stern, 1987; Poterba \& Rotemberg, Fadejeva (2014) evaluated the impact of 1990; Bayoumi \& Gagnon, 1992; Besley \& value added tax on inflation and Latvia and Rosen, 1999; Mankiw \& Reiss, 2002; Carare \& Danninger, 2008; Pike et al. 2009; Christandl et al. 2011; Miki, 2011; Benkovskis et al. 2012; Claus, 2013; Ikpe \& Nteegah, 2013; Benkovskis \& Fadejeva, 2014; Gelardi, 2014; Gatawa et al. 2016). In their research, Poterba and Rotember (1990) determined the positive relationship between inflation and tax rates in United States. On the other hand, Miki (2011) looked how changes of value added tax can affect on aggregate consumption and noticed negative causality between them. Ikpe and Nteegah (2013) analysed the impact of the valueadded tax on inflation and concluded there is a positive and statistically significant impact of this tax form. Similarly, Benkovskis and found that changes of value-added tax rate could have a significant impact on price movements, whereby it is particularly likely at the time of change rate of this tax.

\section{DATA AND ANALYSIS}

In this segment, it is presented the trend of inflation, gross domestic product, unemployment, real interest rate, savings, government expenditures and value-added tax in seven selected economies from 2008 to 2016. Selected countries: Albania, Bosnia and Herzegovina, Croatia, Montenegro, North Macedonia, Serbia and Slovenia.

Figure 1 shows a trend of inflation rate in
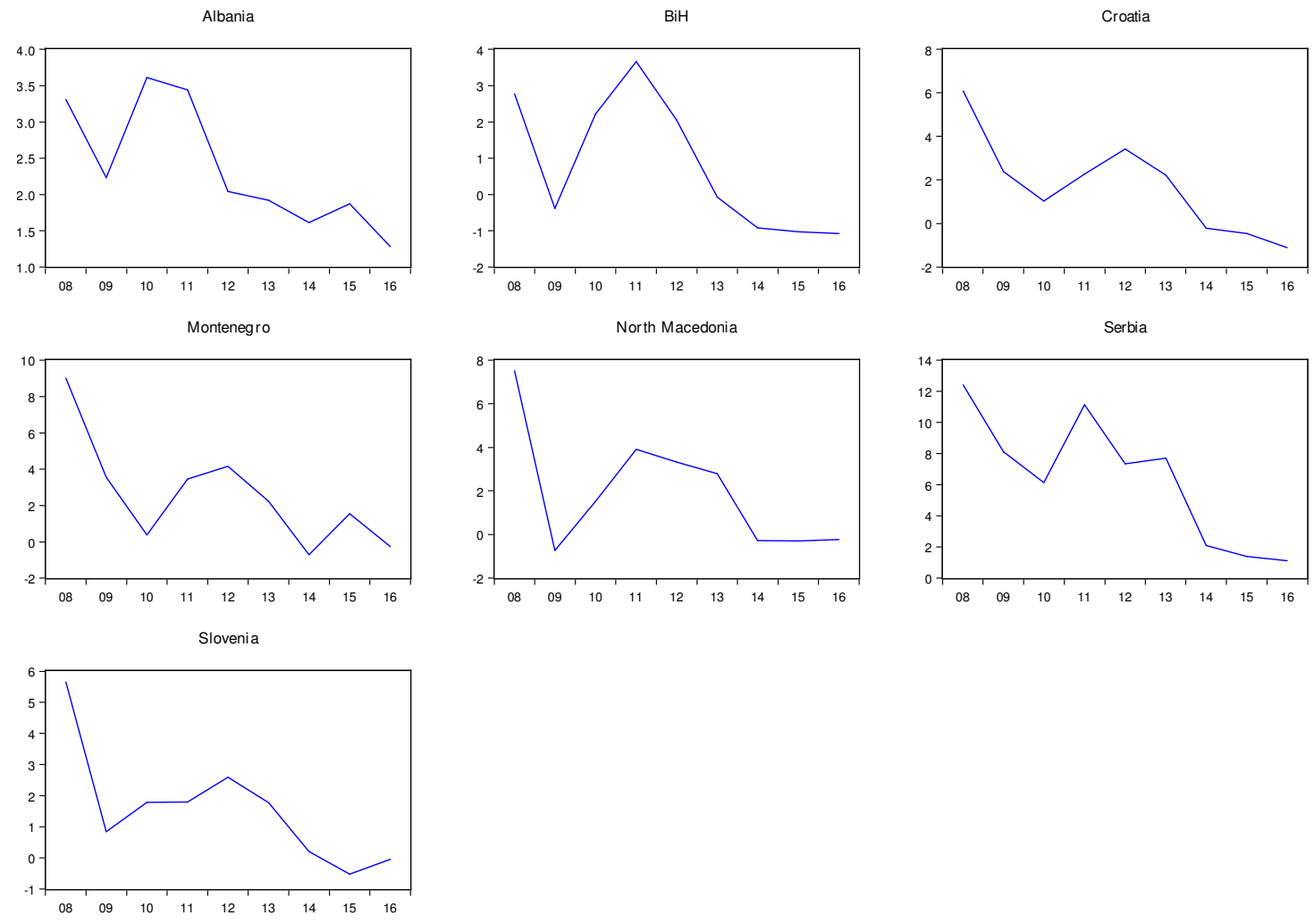

Source: Authors based on International Monetary Fund

Figure 1. Inflation rate in Balkan countries

(Source:Authors based on IMF (2016)) 
selected South East countries from 2008 to 2016. In observed period, Serbia has achieved the highest average inflation rate of $6.44 \%$, which is almost three times more than other countries. The average increase was below 2\% in Bosnia and Herzegovina, Croatia and Slovenia, while other countries had averaged between $2.4-2.8 \%$.

After the escalation of the global economic crisis, there is a similar tendency of GDP rate. This is especially evident in 2009 when this indicator has fallen in all countries. Croatia and Slovenia had a drop of GDP more than $7 \%$, while on the other hand, Albania represents the only economy which achieved a positive growth rate of $3.35 \%$. Looking the unemployment rate, Slovenia had the lowest rate, where the average was $7.69 \%$, which is far less than in North Macedonia where the average was above
30\%. Mojsoska-Blazevski (2012) cited that in 1990 Macedonia was the least developed republic in the former Yugoslavia with the largest unemployment rate of $20 \%$ which is less than today. Slightly lower unemployment was recorded in Bosnia and Herzegovina, while in other countries, the average was at a level of $15 \%$ and $19 \%$.

Finally, value-added tax is presented and as can be seen, Croatia has the highest tax rate of $25 \%$, while value added tax is the lowest of $17 \%$ in Bosnia and Herzegovina. Albania, Bosnia and Herzegovina and North Macedonia didn't change rate of this tax form. In other countries, there was an increase of $1 \%$ or $2 \%$, while Croatia recorded an increase of $3 \%$ from the beginning to the end of time period.
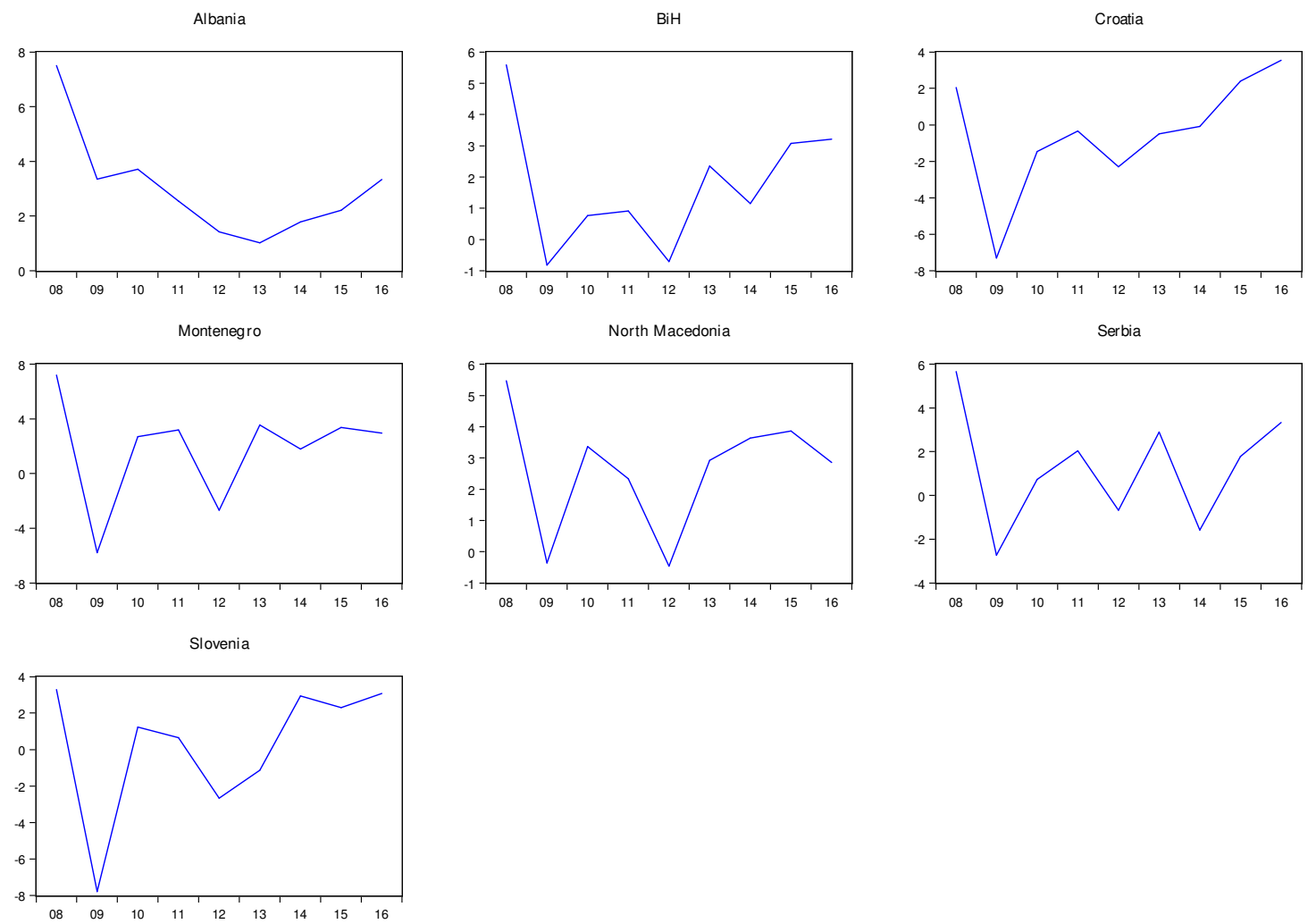

Source: Authors based on International Monetary Fund

Figure 2. Macroeconomic determinants in Balkan countries

(Source:Authors based on IMF (2016)) 

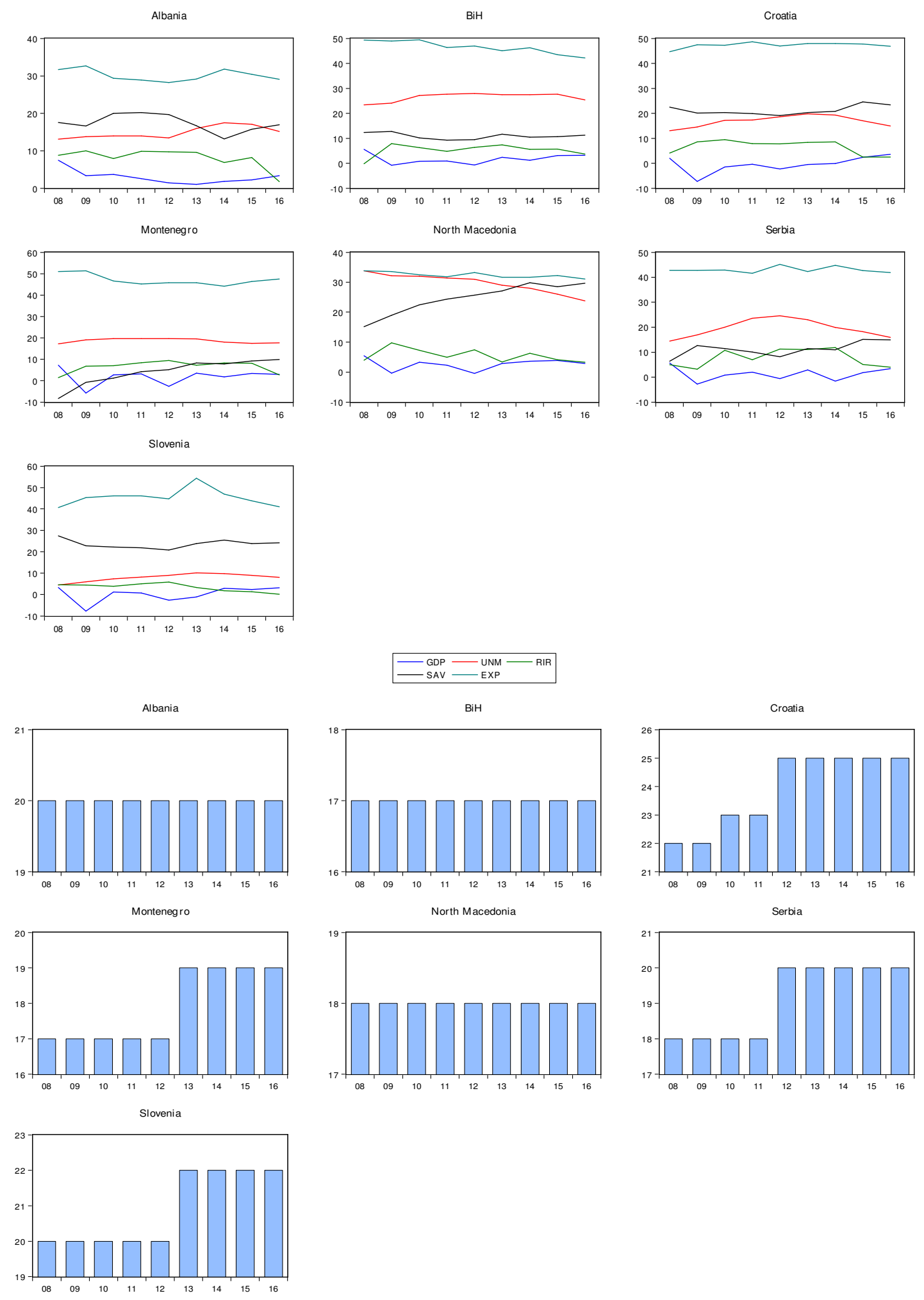

Source: Authors based on KPMG

Figure 3. VAT rate in Balkan countries

(Source: Authors based on KPMG (2016) 


\section{METHODOLOGY}

The paper is focused on the examination of macroeconomic determinants (gross domestic product and unemployment) and tax form (value-added tax) and their impact on price level (inflation) in selected Balkan countries from 2008 to 2016.

Brooks (2008) defined panel regression model:

$$
\begin{aligned}
& Y_{i t}=\alpha+\beta x_{i t}+\mu_{i t} \\
& Y_{i t}=\text { inflation (INF) } \\
& \alpha=\text { constant } \\
& \beta x_{i t} \quad=\text { coefficients of variables (GDP, } \\
& \mathrm{UNM}, \mathrm{VAT}) \\
& i=7 \text { countries } \\
& t=2008-2016 \\
& \mu_{i t}=\text { residual }
\end{aligned}
$$

Observed variables are explained as:

- Inflation - price's rise in the general level, measured by consumer price index;

- Gross domestic product - market value of final goods and services produced within a country in a year, measured by annual rate of growth;

- Unemployment - a situation where someone of working age is not able to get a job, measured by annual rate;

- Real interest rate - an interest rate

Table 1. Variable review

\begin{tabular}{lccl}
\hline Variable & Notation & Calculation & Source \\
\hline Inflation & INF & Annual rate $\%$ & International Monetary Fund \\
Gross domestic product & GDP & Annual rate $\%$ & International Monetary Fund \\
Unemployment & UNM & Annual rate $\%$ & International Monetary Fund \\
Real interest rate & RIR & Annual rate $\%$ & World Bank \\
Savings & SAV & Annual rate $\%$ & \\
Government expenditures & GE & $\%$ of GDP & International Monetary Fund \\
Value added tax & VAT & Annual rate $\%$ & KPMG \\
\hline
\end{tabular}

Source: Authors' illustration

that has been adjusted to remove the effects of inflation to reflect the real cost of funds to the borrower and the real yield to the lender or to an investor;

- Savings - an income not spent, or deferred consumption measured by percentage share of gross domestic product;

- Government expenditures - includes all government consumption, investment, and transfer payments measured by percentage share of gross domestic product;

- Value-added tax - a general consumption tax which is calculated and paid for the delivery of goods and services at all stages of production and trade, as well as their imports, measured by standard rate.

\subsection{Panel model specification}

The Levin-Lin-Chu test is one of the first unit root tests developed for panel data. In order to determine stationary of time series. Levin Lin Chu test is based on analysis of the equation (Levin et al. (2002)):

$$
\begin{aligned}
& \Delta \mathrm{Y}_{i t}=\alpha_{i}+\delta_{i t}+\theta_{t}+\rho_{i} Y_{i}, t-1+s i, t, \\
& i=1,2, \ldots N, t=1,2, \ldots T .
\end{aligned}
$$

The null hypothesis of this test is:

$$
\begin{aligned}
& H_{0}: \rho=0 \\
& H_{0}: \rho<0
\end{aligned}
$$


This test assumes cross-sectionally independence of individual processes. To understand multicollinearity consider the next model (Asteriou \& Hall, 2007):

$$
Y=\beta_{1}+\beta_{2} X_{2}+\beta_{3} X_{3}+\mu
$$

where hypothetical values for $\mathrm{X}_{2}$ and $\mathrm{X}_{3}$ are below:

$$
\begin{aligned}
& X_{2}^{\prime}=12345 \\
& X_{3}^{\prime}=246810
\end{aligned}
$$

We can see that $X_{3}=2 X_{2}$ which means two variable are linearly dependent if one can be expressed as a linear function of the other variable. Hausman test enables making a choice between the fixed effect and random effects model.

$$
\begin{aligned}
& \mathrm{H}=\left(\beta^{\mathrm{FE}}-\beta^{\mathrm{RE}}\right)^{\prime}\left[\operatorname{Var}\left(\beta^{\mathrm{FE}}\right)-\operatorname{Var}\left(\beta^{\mathrm{RE}}\right)\right]^{-1}\left(\beta^{\mathrm{FE}}-\right. \\
& \left.\beta^{\mathrm{RE}}\right) \approx \chi 2(\mathrm{k})
\end{aligned}
$$

If statistic value is large, then the difference between the estimates is significant, so we can reject the null hypothesis that the random effects model is consistent and we use the fixed effects estimators. Contrary, a small value of the Hausman test implies that the random effects estimators is more appropriate.

\section{RESULTS}

Considering that paper researches seven countries in the nine-year period, authors used panel regression model and diagnostics tests for proper selection. First, descriptive statistics presented the value of explanatory variables.

Based on Table 2, the analysis includes seven countries for the period 2008-2016 with 63 analysed observation. As it can see, savings and unemployment, government expenditures have the highest standard deviation, which is three times higher compared to other variables. This can be explained by the fact there is a wide range between the lowest and highest values in selected countries.

Based on Table 3, it can conclude that alternative hypothesis is accepted and confirms that panel series are stationary (pvalue $<0.05$ ).

Authors used VIF test to confirm there is no problem of multicollinearity between observed variables. As we can see, the reference value is lower than 10 which indicates there is no problem of multicollinearity.

Table 5 includes panel regression models which measure the impact of gross domestic product, unemployment, real interest rate, savings, government expenditures and valueadded tax on inflation by evaluation of random effect model and fixed effect model.

Table 2. Descriptive statistics

\begin{tabular}{lccccc}
\hline Variable & Obs. & Mean & Std. Dev. & Min & Max \\
\hline INF & 63 & 2.743651 & 2.919295 & -.9 & 12.41 \\
GDP & 63 & 1.313651 & 2.979413 & -7.78 & 7.53 \\
UNM & 63 & 18.93968 & 7.50545 & 4.4 & 33.8 \\
RIR & 63 & 6.169841 & 2.916457 & -0.25 & 11.78 \\
SAV & 63 & 16.15238 & 7.861274 & -8.29 & 29.79 \\
GE & 63 & 41.69889 & 7.12930 & 28.23 & 54.41 \\
VAT & 63 & 19.66667 & 2.334869 & 17 & 25 \\
\hline
\end{tabular}

Source: Authors' calculation 
Table 3. Levin-Lin-Chu unit-root test

\begin{tabular}{|c|c|c|c|c|}
\hline \multicolumn{5}{|c|}{$\mathrm{H}_{0}$ : Panels contain unit roots } \\
\hline \multicolumn{5}{|c|}{$\mathrm{H}_{\mathrm{a}}$ : Panels are stationary } \\
\hline Variable & Statistic & p-value & $\begin{array}{c}\text { Number of } \\
\text { panels }\end{array}$ & $\begin{array}{c}\text { Accepted/Rejected } \\
\text { Hypothesis }\end{array}$ \\
\hline INF & -7.7677 & 0.0000 & 7 & Rejected $\mathrm{H}_{0}$ \\
\hline GDP & -6.2486 & 0.0000 & 7 & Rejected $\mathrm{H}_{0}$ \\
\hline UNM & -4.9825 & 0.0000 & 7 & Rejected $\mathrm{H}_{0}$ \\
\hline RIR & -6.7181 & 0.0000 & 7 & Rejected $\mathrm{H}_{0}$ \\
\hline SAV & -1.8896 & 0.0294 & 7 & Rejected $\mathrm{H}_{0}$ \\
\hline GE & -1.9030 & 0.0285 & 7 & Rejected $\mathrm{H}_{0}$ \\
\hline VAT & -2.3864 & 0.0085 & 7 & Rejected $\mathrm{H}_{0}$ \\
\hline
\end{tabular}

Source: Authors' calculation

Table 4. Multicollinearity test

\begin{tabular}{ccc}
\hline Variable & VIF & $\mathbf{1 / V I F}$ \\
\hline GDP & 1.56 & 0.640 \\
UNM & 1.47 & 0.680 \\
RIR & 1.7 & 0.588 \\
SAV & 2.59 & 0.386 \\
GE & 2.72 & 0.440 \\
VAT & 2.29 & 0.436 \\
\hline Mean VIF & & \\
\hline
\end{tabular}

Source: Authors' calculation

Table 5. Panel regression model - estimation

\begin{tabular}{lcc}
\hline \multirow{2}{*}{ Variable } & \multicolumn{2}{c}{ Model } \\
\cline { 2 - 3 } GDP & Random effect model & Fixed effect model \\
UNM & 0.062180 & $\mathbf{0 . 2 7 4 9 8 4}$ \\
& $(0.5598)$ & $(0.0183)$ \\
RIR & -0.055244 & $\mathbf{- 0 . 1 8 8 9 7 8}$ \\
& $(0.1981)$ & $(0.0446)$ \\
SAV & 0.063792 & -0.047026 \\
& $(0.5686)$ & $(0.7065)$ \\
GE & $\mathbf{- 0 . 1 4 8 0 3 9}$ & -0.172554 \\
& $(0.0052)$ & $(0.1303)$ \\
VAT & -0.058426 & 0.116191 \\
R-square & $(0.2714)$ & $(0.3950)$ \\
Prob F & -0.025939 & $\mathbf{- 1 . 7 1 4 9 7 7}$ \\
Observation & $(0.8734)$ & $(0.0002)$ \\
\hline
\end{tabular}

Source: Authors' calculation

Both models show a positive impact of the gross domestic product on inflation, where fixed effect model confirms significance of this determinant. It is similar with unemployment, where there is no statistically significant effect on inflation by random effect model, but fixed effect model reflects a significant impact of unemployment. The real interest rate and government expenditures have no significant effect on inflation measured by both models. However, value added significantly affects the inflation measured by fixed effect model, while there is no significance at random effect model. 
Table 6. Hausman test

\begin{tabular}{l|l|l}
\hline \multicolumn{2}{|c}{ Result } & \multicolumn{2}{l}{ Conclusion } \\
\hline $\begin{array}{l}\text { Random effect model vs } \\
\text { fixed effect model }\end{array}$ & chi2(3) $=(\mathrm{b}-\mathrm{B})^{\prime}\left[\left(\mathrm{V}_{-} \mathrm{b}-\mathrm{V} \_\mathrm{B}\right)^{\wedge}(-1)\right](\mathrm{b}-\mathrm{B})=12.65$ & $\begin{array}{l}\text { FE model is an } \\
\text { appropriate }\end{array}$ \\
\cline { 2 - 3 } & Prob $>\mathrm{chi}^{2}=0.0000$ & \\
\hline
\end{tabular}

Source: Authors' calculation

In order to make an adequate selection of model, it was used Hausman test, where result shows that fixed effect model is appropriate $(\mathrm{p}$-value $=0.0055)$. The results showed that $1 \%$ increase of gross domestic product enhances inflation for $0.27 \%$ in observed period. On the other hand, 1\% increase of unemployment decreases inflation for $0.19 \%$. Finally, value added tax negatively affects the inflation, where $1 \%$ increase of this tax declines inflation for $1.71 \%$.

\section{CONCLUSION}

Inflation is one of the most important phenomena in the economy. The concept of inflation and its presence in economic flows can be a problem if there is no adequate monetary policy. Namely, the price increase is a process that can't be stopped, but it can be controlled. There are many factors can have an impact on inflation. In order to define these factors, it is necessary to examine the nature of their nexus with inflation and analyse their potential impact on price growth. The paper manifests the impact of a gross domestic product, unemployment, real interest rate, savings, government expenditures and value-added tax on inflation in countries of the region. The results have shown that gross domestic product and government expenditures have a positive impact on the price level, while on the other hand, unemployment, real interest rate, savings and value-added tax have a negative effect on inflation. Interestingly, results have identified negative relationship between value-added tax, where increase of this tax declines inflation rate. These findings are confirmed previous research of Usman and Adejare (2013) where 1\% increase of VAT decreases inflation for $1.28 \%$. Also, it was identified that gross domestic product and unemployment are significant for inflation in studies such as Malik and Chowdhury (2001) as well as Ademola and Badira (2016). These results enable government of observed countries to focus on growth of gross domestic product and decline of unemployment. Bearing in mind that value-added tax is the most generous tax in selected countries this tax form can cause the inflation rate change. The contribution is reflected through adequate information support to a policy maker about the impact of selected determinants on inflation. Recommendation for policy maker can be intensity growth of gross domestic product which enhances inflation, but simultaneously declines of unemployment can control previous inflation growth. Future research will be focus on OECD countries in order to show comparison and potentially different impact of the same factors on inflation in these economies.

\section{References}

Ademola, A., \& Badiru, A. (2016). The Impact of Unemployment and Inflation on Economic Growth in Nigeria (1981-2014). 


\title{
УТИЦАЈ МАКРОЕКОНОМСКИХ ДЕТЕРМИНАНТИ И ПОРЕСКОГ ОБЛИКА НА ИНФЛАЦИЈУ У ПОЈЕДИНИМ БАЛКАНСКИМ ЗЕМЉАМА
}

\author{
Нада Миленковић, Бранимир Калаш, Вера Мировић и Јелена Андрашић
}

Извод

Циљ истраживања је да се прикаже како бруто домаћи производ, незапосленост, реална каматна стопа, штедња, државни расходи и порез на додату вредност утичу на инфлацију у посматраним балканским земљама за период 2008-2016. године. Истраживање испитује утицај макроекономских детерминанти на кретање цена на општем нивоу, мерено годишњом стопом инфлације. Посматране земље су Албанија, Босна и Херцеговина, Хрватска, Црна Гора, Северна Македонија, Србија и Словенија. Овај рад укључује модел где је инфлација зависна промењива, док бруто домаћи производ, незапосленост, реална каматна стопа, штедња, државни расходи и порез на додату вредност представљају независне промењиве. Аутори су користили LLC тест и VIF тест за стационарност и мултиколинеарност, где је потврђено да је модел адекватно дизајниран. Путем Hausman тест-а, изабран је модел фиксног ефекта где је потврђено да бруто домаћи производ, незапосленост и порез на додату вредност имају статистички значајан утицај на инфлацију у поређењу са осталим посматраним варијаблама у моделу.

Кључне речи: инфлација, макроекономске детерминанте, панел модел, балканске земље.

International Journal of Business and Economic Sciences Applied Research, 9 (1), 47-55.

Aminu, U., \& Manu, D. (2014). The growth effects of unemployed resources and inflation in Nigeria. Journal of Economics and Sustainable Development, 5 (2), 108122.

Asteriou, D., \& Hall, S. (2007). Applied Econometrics. NY, USA: Palgrave Macmillan.

Attari, M.I.J., \& Javed, A.Y. (2013). Inflation, Economic Growth and Government Expenditure of Pakistan:19802010, Procedia Economics and Finances, 5, 58-67.

Bağci, E., \& Ergüven, E. (2015). Relations between Interest Rate, Inflation, Growth and Investment in Turkey, 20022015, Journal of Economics and Finance, 7 (5), 43-49.
Baharumshah, A.Z., Slesman, L., \& Wohar, M.E. (2016). Inflation, inflation uncertainty and economic growth in emerging and developing countries: Panel data evidence. Economic Systems, 40 (4), 638-657.

Bayoumi, T. \& Gagnon, J. (1992). Taxation and Inflation: A New Explanation for Current Account Imbalances, International Finance Discussion Papers 420, Board of Governors of the Federal Reserve System.

Benkovskis, K., Fadejeva, L., \& Kalnberzina, K. (2012). Price setting behaviour in Latvia: Econometric evidence from CPI micro data. Economic modelling, 29 (6), 2115-2124.

Benkovskis, K., \& Fadejeva, L. (2014). The effect of VAT rate on inflation in Latvia: evidence from CPI microdata. Applied Economics, 46 (21), 2520-2533. 
Besley, T.J., \& Rosen, H.S. (1999). Sales Taxes and Prices: An Empirical Analysis. National Tax Journal, 52 (2), 157-178.

Brooks, C. (2008). Introductory Econometrics for Finance. Cambridge, UK: Cambridge, University Press.

Carare, A., \& Danninger, S. (2008). Inflation Smoothing and the Modes Effect of VAT in Germany. International Monetary Fund, IMF Working Paper WP 08/175, Washington.

Christandl, F., Fetchenhauer, D., \& Hoelzl, E. (2011). Price perception and confirmation bias in the context of a VAT increase? Journal of Economic Psychology, 32, 131-141.

Claus, I. (2013). Is the value added tax a useful macroeconomic stabilization instrument? Economic Modelling, 30, 366374.

Domac, I., \& Elbirt, C. (1998). The Main Determinants of Inflation in Albania, Policy Research Working Paper, No. 1930, Washington, World Bank.

Dotsey, M., \& Sarte, P. (2000). Inflation uncertainty and growth in a cash-in-advance economy, Journal of Monetary Economics, 45 (3), 631-655.

Edeme, R.K., \& Ifelunini. I. (2015). Savings, Inflation and Economic Growth Linkages: A Re-Examination with Nigera Data, The Journal of Investment Management, 4 (5), 180-185.

Enu, P., Attah-Obeng, P., \& Hagan, E. (2013). The relationship between gdp growth rate and inflationary rate in Ghana: An elementary statistical approach. Academic Research International, 4 (5), 310-318.

Ferdous, M., \& Shahid, E. (2013). Study on nature of inflation and its relationship with GDP growth rate: a Case Study on Bangladesh. Journal of Economics and Finance, 1 (3), 40-49.
Fountas, S. (2010). Inflation, inflation uncertainty and growth: Are they related? Economic Modelling, 27, 5, 896-899.

Friedman, M. (1976). Inflation and Unemployment-Nobel Memorial Lecture, The University of Chicago, Illinois, United States.

Gatawa, N.M., Aliero, H.M., \& Aishatu, A.M. (2016). Evaluating the impact of value added tax on the economic growth of Nigeria. Journal of Accounting and Taxation, 8 (6), 59-65.

Gelardi, A. (2014). Value Added Tax and Inflation: A Graphical and Statistical Analysis. Asian Journal of Finance \& Accounting, 6 (1), 138-158.

Haderi, S., Papapanagos, H., Sanfey, P., \& Talka, M. (1999). Inflation and Stabilisation in Albania, Post-Communist Economies, 11 (1), 127-141.

Ikpe, M., \& Nteegah, A. (2013). Value Added Tax and price stability in Nigeria: A partial equilibrium analysis. European Journal of Government and Economics, 2 (3), 137-147.

IMF. (2016). World Economic Outlook, Washington, DC: International Monetary Fund

Jha, R., \& Dang, T. (2012). Inflation variability and the relationship between inflation and growth, Macroeconomics and Finance in Emerging Market Economies, 5 (1), 1-15.

Klomp, J., \& Haan, J. (2009). Political institutions and economic volatility, European Journal of Political Economy, 25, 311-326.

KPMG. (2016). Retrieved from https:/home.kpmg.com/xx/en/home/service s/tax/tax-tools-and-resources/tax-ratesonline/indirect-tax-rates-table.html

Levin, A., Lin, C.F., \& Chu, C.S.J. (2002). Unit root tests in panel data: asymptotic and 
finite-sample properties. Journal of Econometrics, 108, 1-24, DOI: 10.1016/S0304-4076(01)00098-7.

Malik, G., \& Chowdhury, A. (2001). Inflation and Economic Growth: Evidence from Four South Asian Countries. Asian Pacific Development Journal, 8 (1), 123-135.

Mankiw, G., \& Reis, R. (2002). Sticky Information Versus Sticky Prices: A Proposal to Replace the New Keynesian Phiillips Curve. Quarterly Journal of Economics, 117 (4), 1295-1328.

Mehrara, M., \& Sujoudi, A. (2015). The Relationship between Money, Government Spending and Inflaton in the Iranian Economy. International Letters of Social and Humanistic Sciences, 51, 89-94.

Miki, B. (2011). The Effect of the VAT Rate Change on Aggregate Consumption and Economic Growth, Columbia University, Center on Japanese Economy and Business, Working Paper Series 297.

Milenković, I., Kalaš, B., \& Andrašić, J. (2017). Macroeconomic determinants of economic growth in Serbia, Facta Universitatis Series: Economics and Organization, 14 (2), 105-115.

Mojsoska-Blazevski, N. (2012). Taxation of labour: the effect of labour taxes and costs on employment in Macedonia, PostCommunist Economies, 24 (2), 241-256.

Pike, R., Lewis, M., \& Turner, D. (2009). Impact of VAT reduction on the consumer price indices. Economic and Labour Market Review, 3 (8), 17-22.

Poterba, J.M., \& Rotemberg, J.J. (1990). Inflation and Taxation with Optimizing Governments. Journal of Money, Credit and Banking, 22 (1), 1-18.

Rother, P. (2002). Inflation in Albania, Post-Communist Economies, 14 (1), 85-107.

Schall, L. (1984). Taxes, Inflation and Corporate Financial Policy. The Journal of
Finance, The American Finance Association, 39 (1), 105-126.

Stern, N. (1987). The effects of taxation price control and government contracts in oligopoly and monopolistic competition. Journal of Public Economics, 32, 133-158.

Usman, O., \& Adejare, A. (2013). Value added tax and economic growth: The Nigeria experiance (1994-2010), International Journal of Research in Commerce, IT \& Management, 3 (3), 85-89.

Yelwa, M., David, O., \& Omoniyi, A. (2015). Analysis of the Relationship between Inflation, Unemployment and Economic Growth in Nigeria: 1987-2012. Applied Economics and Finance, 2 (3), 102-109.

Žižmond, E. (1991). Inflation and price stabilisation policy in Yugoslavia, Communist Economies and Economic Transformation, 3 (2), 187-200. 